\title{
PRÁVNÍ POSTAVENÍ SPORTOVNÍCH TRENÉRŮ V ČESKÉ REPUBLICE
}

\author{
DAVID KOHOUT*
}

\begin{abstract}
Legal Position of Sport Coaches in the Czech Republic
This article seeks to review the legal position of sport coaches in the Czech Republic. It examines the general legal framework for their activity in terms of the applicable public and private law regulation. More specifically it looks into the contractual basis of their relationship with sport clubs and individual athletes, which is very variable in terms of the types of contracts used under the Czech law and usually using other types of contracts than employment contract. The reason for this can seen principally in the absence of specific sport-based type of contract, which would be foreseen for such legal relationships in the Czech Republic (in contrast to a number of other countries, which adopted legislation in this respect). From another perspective, this article also discusses the impact of internal regulation of sport associations on the performance of coaches' duties in the respective sport discipline. This regulation also has significant impact on the coaches as it governs the system of their licencing and thus sets out eligibility criteria for exercising their profession.
\end{abstract}

Keywords: coach; sports law; sport; sports contracts

Klíčová slova: trenér; sportovní právo; sport; smlouvy ve sportu

DOI: $10.14712 / 23366478.2019 .3$

\section{ÚVODNÍ PŘEDZNAMENÁNÍ}

Z hlediska společenského a mediální vnímání sportu se zdá být obsazení pozice trenéra nejen $\mathrm{v}$ kolektivních sportech jednou z klíčových premis cesty za sportovním úspěchem. Trenér má ve sportu ${ }^{1} \mathrm{v}$ obecné rovině přispívat $\mathrm{k}$ rozvoji výkonnosti sportovců a tím pomoci dosáhnout i kolektivních zájmů jejich sportovních klubů prostřednictvím těchto, $\mathrm{v}$ daných klubech, oddílech či střediscích, registrovaných

* JUDr. David Kohout, Ph.D., je vedoucím oddělení pro zahraniční styky Právnické fakulty Univerzity Karlovy, vědeckým pracovníkem Centra mimosoudního řešení sporů tamtéž a členem Sboru rozhodců Fotbalové asociace Ceské republiky.

1 Srov. též dokument Ministerstva školství, mládeže a tělovýchovy: Přehled odborností pro žadatele o akreditaci vzdělávacím zařízení v oblasti sportu. Dostupné online na: <http://www.msmt.cz/file/48228/>. [cit. 31. 10. 2018]. 
sportovců. ${ }^{2}$ Těmito kolektivními zájmy je ve smyslu obecného soutěživého ${ }^{3}$ rozměru sportu především prezentace jména vlastního klubu/oddílu 4 (popř. v rámci sportovní reprezentace vlastního státu) a zvýšení jeho popularity jakožto moderní alternativy středověkých a raně moderních ideálů slávy na poli válečném a milostném.

Velmi trefně toto vystihuje M. Colucci, když píše: „Mají neskutečnou odpovědnost za posouvání svého týmu k úspěchu. Motivuji hráče a pomáhaji jim naplno rozvinout svioj talent, uči je fotbalové dovednosti a pomáhaji hráčùm maximalizovat jejich talent a vybrousit virtuozitu těch nejlepšich hráču. Jsou společenskými vzory a jako takoví maji důležitý vliv na chování hráčů jak na hřišti, tak mimo něj. "5

Tento text si však klade za cíl představit pozici sportovních trenérů z ryze pragmatického pohledu právního rámce jejich fungování pro jednotlivé sportovní organizace v kontextu smluvního rámce této činnosti a specifik sportovního prostředí v České republice. Je zde nutné míti na paměti, že trenérská činnost se v dnešní době realizuje v celé řadě forem. Trenéŕi působí u klubů či reprezentačních výběrů věnujících se kolektivním sportům i sportům individuálním. Tréninková činnost se uskutečňuje $\mathrm{v}$ př́padě sportovců, kteří se účastní soutěží organizovaných zastřešující organizacíb i v př́ípadě sportovců, kteří mají ryze osobní výkonnostní ambice mimo účast na sportovních utkáních či soutěžích 7 . Podporují sportovce na ryze amatérské úrovni, kdy vykonávají svou činnost na dobrovolnické a mnohdy smluvně blíže neregulované bázi. Jsou však i trenéři, kteří za svou činnost od klubu získávají dílčí odměnu, avšak hlavním zdrojem jejich př́ijmu je činnost zcela jiná. Na nejvyšší úrovni se pak můžeme setkat s osobami, které výkon „trenérského řemesla“ mají jako hlavní zdroj svých př́imů a jedná se tak v jejich podání o profesionální výkon trenérství. Všechny tyto modality je možné uchopit po stránce obecného právního rámce pro jejich uskutečňování, stejně jako z pohledu př́ipadné interní regulatoriky sportovních odvětví, která nezřídka mají vlastní doplňující předpisy pro podmínky výkonu trenérské činnosti v př́slušném sportu.

2 Sportovcem příslušejícím ke sportovnímu klubu můžeme rozumět podle $§ 2$ odst. 3 zákona č. 115/2001 Sb., o podpoře sportu, především „,každou fyzickou osobu, která v daném kalendárním roce skutečně vykonává sportovni ćinnost, pro kterou je u sportovni organizace evidována“.

3 V dnešní době však postupně více a více komercionalizovaného rozměru sportu.

4 Termín oddíl je v tomto smyslu uživán pro složku klubu zpravidla bez vlastní právní subjektivity, který je organizačně vyčleněn v rámci vnitřní struktury klubu. Př́íkladem může být např. Tělovýchovná jednota Turnov, z. s., která v rámci jednotné právnické osoby (spolek podle § 214 a násl. zákona č. 89/2012 Sb., občanský zákoník - dále jen „OZ“) uvádí v rámci své vnitřní struktury 20 různých oddílů pro jednotlivé sporty - např. aerobik, box, florbal, musherství. Jiným případem mohou být sportovní oddíly, které jsou od svého mateřského klubu právně odvislé ve formě tzv. pobočných spolků podle $§ 228$ a násl. OZ. V takovém príípadě sice disponují oddíly vlastní právní osobností, ale jsou ve své existenci právně závislé do značné míry na svém „hlavním spolku“. Jako příklad mohou sloužit jednotlivé sokolské jednoty, které jsou sice odvislé od celostátní České obce sokolské, ale mají vlastní právní osobnost - např. Tělocvičná jednota Sokol Vsetín, pobočný spolek.

5 COLUCCI, M. Foreword. In: VANDELLÓS ALAMILLA, J. F. Football Coach-related Disputes. A Critical Analysis of the FIFA Players 'Status Committe Decisions and CAS Awards. B. n.: Sports Law and Policy Centre, 2018, s. 11.

6 Zastřešující organizací je míněna sportovní asociace (ve sportovní praxi vždy spolek), at' již se jedná o asociaci typicky na úrovni celostátní (napřr. Fotbalová asociace České republiky - dále jen „FAČR“), či úrovni mezinárodní (nap̌r. Union of European Football Associations - dále jen „UEFA“), která organizuje podle vlastních herních a soutěžních pravidel př́slušnou soutěž.

7 Viz např. fitness trenéři. 
V české odborné literatuře již bylo poměrně hodně napsáno o právním postavení aktivních sportovců s přihlédnutím $\mathrm{k}$ historickému i současnému právnímu stavu v kontextu soudní rozhodovací praxe, a to především v oblasti kolektivních sportů. ${ }^{8}$ Právnímu postavení sportovních trenérů však doposud nebyla věnována ucelená pozornost. ${ }^{9}$ Jejich postavení je oproti aktivním sportovcům v praxi českého sportu rozmanitější, i když hlavní principy jejich faktického fungování jsou do značné míry nakonec obdobné. Jedním z podstatnějších rozdílů může být především interní regulace pro činnost sportovních trenérů z hlediska sportovních asociací, např. licencování těchto osob. V České republice však, na rozdíl od právní úpravy (velké většiny) evropských zemí, nefunguje systém centrální státní registrace trenérů jako zvláštní státem uznávané kategorie regulovaných „sportovních odborníkü“.

\section{SPORTOVNÍ TRENÉŘI V ČESKÉ REPUBLICE Z HLEDISKA OBECNÉHO PRÁVNÍHO RÁMCE JEJICH ČINNOSTI}

Právní řád České republiky s pojmem „sportovní trenér“ operuje jen v omezeném rozsahu a nikde jej nedefinuje. $Z$ kontextu je však zřejmé, že z pohledu právní úpravy je profese trenéra zohledňována spíše jen jako kategorie ekonomické činnosti. Základní právní předpis, který je v České republice zaměřen specificky na oblast sportu, tj. zákon o podpoře sportu, je spíše jen jakousi kompetenční normou veřejnoprávního charakteru. ${ }^{10}$ Ve svém $\S 1$ a obecně proklamativně stanovuje, že ,základními prioritami v oblasti sportu je podpora sportu dětí a mládeže a jejich trenérů a podpora sportovnich reprezentantů České republiky", a v dalších ustanovení obecně ukládá Ministerstvu školství, mládeže a tělovýchovy vytvářet vhodné podmínky především pro činnost trenérů dětí a mládeže. Funkci trenéra zmiňuje zákon dále již jen v kontextu připravovaného „rejstřiku sportovních organizací žádajicích o podporu ze státního rozpočtu podle § 6 b nebo 6 c a sportovcü, trenéru a sportovních zařizení, na jejichž činnost se žádá o poskytnutí této podpory“ (§ 3 odst. 1 písm. j)). ${ }^{11} \mathrm{~V}$ současné době

8 Srov. zejména PICHRT, J. (ed.). Sport a (nejen) pracovní právo. Praha: Wolters Kluwer, 2014; JURKA, H. Právní úprava profesionálního sportu v České republice a v zahraničí. Praha: Wolters Kluwer, 2018.

9 Srov. např. i jejich úplné opomenutí ve výčtu fyzických osob vyskytujících se v oblasti sportu: KUBÍČEK, J., Sport a právo, s. 99. Dostupné online na: <https://is.muni.cz/el/1451/podzim2013/np2330 /um/44387142/0_Sport_a_pravo_2c_skripta_2c_Jiri_Kubicek_2c_2012.pdf > [cit. 31. 10. 2018].

10 Zákon č. 115/200̄ $1 \mathrm{Sb}$., o podpoře sportu.

$11 \mathrm{Tj}$. v rámci výzev dotačních programů Ministerstva školství, mládeže a tělovýchovy je možné žádat též o prostředky za účelem podpory trenérů ve sportovních klubech (na neprofesionální úrovni), popř. pro účely zajišsění sportovní reprezentace České republiky. K tomuto je možno pro bližší osvětlení využít citaci z důvodové zprávy k návrhu novely zákona o podpoře sportu z roku 2018 (sněmovní tisk č. 241/0): „Oproti dosavadnímu zněni zákona o podpoře sportu nedocházi k rozšíreni účelu, ke kterému má být dotace na podporu sportu sportovním organizacím poskytována. S ohledem na existujici interpretační problémy se navrhuje pouze upresnit, že výdaji na podporu sportu, na něž může být agenturou dotace poskytnuta, jsou oprávnèné výdaje na činnost sportovnich organizací spojené s podporou sportu zaměrenou zejména na podporu sportu dětí a mládeže, sportu pro všechny, sportu zdravotně postižených osob a na podporu úspěšných sportovnich reprezentantů České republiky, tedy prioritami v oblasti sportu stanovenými zákonem o podpoře sportu. Druhové rozlišení oprávněných výdajů na činnost sportovnich organizací stanoví agentura v programech, na základě kterých bude podporu v oblasti sportu poskytovat. Typicky se pritom 
projednávaný návrh novely zákona na podporu sportu (sněmovní tisk č. 241/0 z roku 2018) na tomto opomíjejícím prrístupu nic nemění, uvedené pravomoci Ministerstva by „pouze“ měly přejít na nově vytvářenou Národní sportovní agenturu.

Český př́stup je v ostrém kontrastu k úpravě trenérské profese na Slovensku, kde byla vtělena do zvláštní zákonné úpravy zákona č. 440/2015 Z. z., o športe. Podle něj se sportovní trenér počítá za tzv. „sportovniho odborníka“ (§ 6 odst. 1 písm. a)), který má tuto pozici oprávnění zastávat teprve okamžikem zápisu do veřejného „registru osob ve sportu“. 12 Podobně jako v České republice, jak bude dále podrobněji rozvedeno, počítá však slovenská úprava s mnohostí právních forem výkonu takto registrované trenérské činnosti. Jedná se o tyto modality: výkon činnosti na základě živnostenského oprávnění, na základě smlouvy o výkonu činnosti sportovního odborníka, na základě pracovněprávního vztahu či jiného pracovněprávního vztahu, jako dobrovolník či zcela bez smluvního základu (§ 6 odst. 3).

Z tohoto výčtu se českýma očima jeví jako nejzajímavější úprava smlouvy o výkonu činnosti sportovního odborníka, jež je jako specifický smluvní typ zákonem o športe $\mathrm{v} \S 49 \mathrm{a}$ upravována. ${ }^{13}$ Předepisována je pro ni písemná forma s tím, že jejími podstatnými náležitostmi jsou stanovení druhu činnosti (v tomto našem případě trenérské, druhů sportovních odborníků je však více), odměny a doby, na níž je smlouva uzavírána. Ta může činit maximálně 12 měsíců, s možností opětovného uzavření smlouvy (bez omezení počtu opakování, což může být podstatným znakem odlišujícím tento smluvní typ od pracovněprávních vztahů na dobu určitou ${ }^{14}$ ). Maximální počet hodin, které může sportovní odborník podle tohoto typu smlouvy pro klub vykázat, je 30 hodin týdně a 12 hodin $\mathrm{v}$ průběhu 24 po sobě jdoucích hodin. Tento typ smlouvy také obsahuje zákaz zahrnutí konkurenční doložky pro dobu po skončení platnosti smlouvy, kterou je možno ukončit dohodou či výpovědí se standardní výpovědní dobou 15 dní od písemného doručení výpovědi, není-li ve smlouvě ujednán i jiný možný způsob ukončení smlouvy. Na smlouvu se pohlíží jako na tzv. jiný pracovněprávní vztah ve smyslu $§ 1$ odst. 3 zákoníku práce, z nějž se enumerativním výčtem na smlouvu o výkonu činnosti sportovního odborníka vztahují některá ustanovení (o minimální mzdě, ochraně při práci a dále vybraná ustanovení z úpravy dohod uzavíraných mimo pracovní poměr - především obecné vzájemné povinnosti smluvních stran a odpovědnost za způsobenou škodu).

Slovenský zákon také dává výslovné oprávnění národním sportovním svazům, aby pro sportovní odborníky (v tomto prŕípadě trenéry) předepisovaly požadované podmínky odborné způsobilosti, v což můžeme jistě zahrnout i vnitřní svazové systémy licencování či proškolování trenérů na různých úrovních (§ 16 odst. 2 písm. i)). Obsah školení trenéru je pak dále prohlubován $\mathrm{v} \S 83$, kde se pro trenéry určuje 5 různých kvalifikačních stupňủ, jež mohou získat cestou vzdělávacích programů poskytovaných školskými subjekty či sportovními svazy.

bude jednat o úhradu nákladi̊ spojených se zajištěním trenérů, rozhodčich, dopravy na sportovní utkání apod."

12 Nad tento rámec zná zákon o športe např. i kategorii ,instruktor športu“ jakožto zvláštní druh sportovního odborníka (§ 6 odst. 1 písm a)).

13 K smluvním vztahům ve sportu na Slovensku obecně srov. § 31 a násl. zákona č. 440/2015 Z. z.

14 Srov. § 48 zákona č. 311/2001 Z. z., zákonník práce. 
Jak již bylo uvedeno výše, v České republice v současnosti žádná výslovně stanovená legislativní vodítka k právnímu rámci fungování trenérů nenalezneme. Bylo a je tudíž ponecháno na právní praxi, jak vztahy mezi trenéry a sportovními kluby či dalšími subjekty uspořádá. Situace je tak ne nepodobná úpravě postavení aktivních sportovců v celém spektru jejich možných postavení. Lze proto souhlasit s J. Kubíčkem, když uvádí, že „vzájemné vztahy mezi sportovními subjekty vykazují velkou míru autonomie podobně jako právní úprava postaveni sportu. Pro značnou rozmanitost jednotlivých vztahů (kolektivni sporty / individuálni sporty), postavení sportovců (profesionál / poloprofesionál / amatér), charakter vztahů (osobni / obchodni) nebo délku vztahů (smluvni dlouhodobé - hráčské / pro jednotlivou akci-pořadatel, rozhodči) je tato oblast velmi členitá. "15

Z pohledu sportovců se totiž setkáme v České republice se situací, která, dá se ř́ci, překlenuje legislativní vakuum dlouhodobou praxí posvěcenou soudními rozhodnutími. V kolektivních sportech se historicky setkáváme s tím, že sportovci vykonávají svou činnost pro klub nikoliv ve formě zaměstnanců, nýbrž ve formě osob samostatně výdělečně činných. Hlavní důvody, které $\mathrm{k}$ tomu vedou, lze $\mathrm{v}$ krátkosti shrnout takto: systém odměňování za sportovní výkony je mnohdy odvozen od sportovních výsledků a obsahuje systému smluvních bonusů či naopak malusů, s čímž standardní pracovněprávní úprava nepočítá; problematika „pracovní doby“ u sportovců je vysoce variabilní a vymyká se pracovněprávnímu standardu; špatná využitelnost stávající úpravy řetězení pracovních smluv na dobu určitou; problematika výpovědních důvodů podle pracovního práva, která pro oblast sportu mimo jiné znevýhodňuje př́ípadného zaměstnavatele, jemuž by mohl dát hráč kdykoliv výpověd', byt' do jeho angažování třeba klub na přestupovém trhu investoval nemalé finanční prostředky. ${ }^{16} \mathrm{~V}$ neposlední řadě se ze sportovních kruhů ozývá, že podřazení sportovců pod zaměstnanecký režim by přineslo klubům nemalé finanční obtíže vzhledem k zvýšeným nákladům na pojistné odváděné za zaměstnance zaměstnavatelem. ${ }^{17}$ To vše vedlo praxi $\mathrm{k}$ jiné cestě úpravy smluvních vztahů $\mathrm{v}$ kolektivních sportech než cestou smluv podle zákoníku práce.

Lze mít za to, že judikatura českých soudů posvěcující v oblasti výkonných sportovců $\mathrm{v}$ kolektivních sportech tento stav je odborné veřejnosti poměrně známá. Vůdčím rozsudkem pak zřejmě je rozsudek Nejvyššího správního soudu ze dne 29. 11. 2011, spis. zn. 2 Afs 16/2011, v němž soud shledal následující:

„Činnost sportovce se pojmovému vymezeni závislé ćinnosti sice velmi bliží, nicméně nedosahuje její intenzity. Jakkoliv se totiž stěžovatel musel při své činnosti ř́dit pokyny svého smluvního partnera (klubu - ,zaměstnavatele') a měl právo od něj dostávat př́-

15 KUBÍČEK, c. d., s. 133.

16 Srov. k tomuto např. STÁDNÍK, J. Sportovní činnost a závislá práce. In. PICHRT, c. d., s. 80-82; či GREGUŠ, J. Vyváženost’ práv a povinností medzi športovou organizáciou a športovcom v zákone o športe. In: BARANCOVÁ, H. - OLŠOVSKÁ, A. (eds.). Súčasný stav a nové úlohy pracovného práva. Praha: Leges, 2016, s. 367-369.

17 PICHRT, J. Profesionálni sportovec zaměstnancem? In: PICHRT (ed.). c. d., s. 16. S tímto je nyní konfrontován sportovní sektor na Slovensku, kde by k 1. 1. 2019 měly být za zaměstnané sportovce kluby odváděny odvody na pojištěné v plné výši. K situaci na Slovensku a obavám spojeným s touto otázkou srov. SEPEŠI, P. Závery okrúhleho stola $k$ téme odvodov profesionálnych športovcov - zamestnancov. Záznam a závěry diskuze v rámci kulatého stolu na konferenci „Šport a právo 2018“. Dostupné online na: $<$ http://www.ucps.sk/Zavery_okruhleho_stola_k_teme_odvodov $>$ [cit. 31. 10. 2018]. 
slušnou sjednanou odměnu, zejména v povinnosti sportovce vykonávat práci ,v pracovni době nebo jinak stanovené nebo dohodnuté době na pracovišti zaměstnavatele, poprípadě na jiném dohodnutém mistě je činnost profesionálního sportovce natolik specifická, že se omezením plynoucím ze zaměření a výslovné reglementace zákoníku práce vymyká. Z povahy věci je totiž zřejmé, že součástí výkonu činnosti profesionálního sportovce není pouze účast na utkáních, př́padně trénincích, svého klubu, nýbrž i řada dalšich aktivit, které jsou nezbytné jednak pro stoprocentní pripravenost daného sportovce [...] a také z di̊vodi̊ marketingových zájmů klubu (reklamní akce, autogramiády, setkání s fanoušky atp.). V konečném di̊sledku je proto obtížně představitelné, aby specifická činnost profesionálního sportovce v běžici sezóně byla svojí povahou slučitelná s takovými instituty zákoníku práce, jako jsou třeba nepřetržitý odpočinek mezi dvěma směnami, prestávky v práci na jídlo a oddech, dny pracovního klidu anebo práce přesčas. I kdyby však tato úskalí byla tvořivou aplikaci zákoníku práce překonána, je na smluvních stranách, aby i z di̊vodi̊ obtižné použitelnosti zákoníku práce na činnost stěžovatele, zvolily jinou smluvní úpravu, byla-li podle soukromého práva možná. [...] lze tak učinit dílči závěr, že činnost profesionálního sportovce není jednoduše podřaditelná pod pojem ,závislá práce“ ve smyslu zákoniku práce. Nelze proto vyloučit, resp. dokonce považovat za protiprávní, uzavírání i jiných než pracovních smluv mezi sportovci a jejich kluby. Tento závěr lze ostatně opřit i o faktickou situaci, kdy je v praxi obecně akceptováno, že profesionálni sportovec může - z daňového hlediska - působit též jako OSVČ [...]. K odklonu od této obecně akceptované praxe by proto musel existovat velmi silný di̊vod, spočívající např. ve výslovné změně zákonné úpravy. Jinak totiž lze argumentovat i prostřednictvím určité míry normativni sily fakticity."18

Tuto dlouhodobě konzistentní judikaturní linii českých soudů potvrdil a dále prohloubil i nedávný rozsudek Nejvyššího správního soudu v př́ípadu fotbalového útočníka Davida Lafaty ze dne 13. 7. 2017, spis. zn. 6 Afs 278/2016-54. Ř́zení fakticky v tomto případě rovněž jako v případě předešlého rozhodnutí vzešlo z problematiky aplikace daňových předpisů na oblast právních vztahů ve sportu. Sportovec totiž danil své př́ijmy jako osoba samostatně výdělečně činná vykonávající tuto činnost na základě živnostenského oprávnění. S tím je oproti OSVČ vykonávající tzv. svobodné povolání spojeno daňové zvýhodnění spočívající v tom, že jako živnostník si může osoba uplatňovat tzv. výdajové paušály až do výše 60 \% svých př́immů (maximálně do výše výdajů $600.000 \mathrm{Kč}$ ), zatímco v prípadě svobodných povolání je tento paušál stanoven hranicí 40 \% prŕíjmů (a maximálně do výše výdajů 400.000 Kč). ${ }^{19}$,Živnostenský model“" se tak z hlediska daňové optimalizace jeví jako výhodnější, čehož proto David Lafata využíval a byl v držení živnostenského oprávnění pro svou činnost fotbalového hráče (a nutno dodat, že takto postupuje v praxi České republiky většina profesionální sportovců nejen v kolektivních sportech).

Tento postup Davidovi Lafatovi vytkl finanční úřad v rámci daňové kontroly a uložil mu dodanit cca. 870.000 Kč a uhradit k tomu daňové penále ve výši cca. 174.000 Kč.

18 Srov. odst. 28 a 30 citovaného rozsudku.

19 Viz $§ 7$ odst. 7 zákona č. 586/1992 Sb., o daních z př́ijmu. 
Fotbalový útočník s tímto nesouhlasil a cestou opravných prostředků dospěl s tímto sporem až k Nejvyššímu správnímu soudu, jenž se v rozsudku vyjádřil následně:

„Legální definici nezávislého povolání ani výčet činností, které pod daný pojem spadaji, žádný právní predpis neobsahuje. Jak vyplývá z rozsudku Nejvyššiho správního soudu ze dne 21. 9. 2011, čj. 8 Afs 56/2010-73, č. 2571/2012 Sb. NSS, ve vztahu k obsahu tohoto pojmu lze podpưrně využit § 22 odst. 1 písm. f) zákona o danich z príjmů, $k$ de se v souvislosti s daňovými nerezidenty operuje s pojmem nezávislá činnost. Při vědomí, že některé z tam uvedených činností je třeba považovat za podnikání podle jiných právnich předpisů (architekt, lékař, inženýr, právnik), lze za nezávislá povolání považovat např. výkonné umělce, sportovce, jejich trenéry, rozhodčí, artisty apod. Pro zminěné profese je charakteristická kreativita a samostatnost při volbě způsobu, jakým bude dosaženo predem stanoveného výsledku.

Živností se dle § 2 živnostenského zákona rozumí, soustavná činnost provozovaná samostatně, vlastním jménem, na vlastni odpovědnost, za účelem dosažení zisku a za podminek stanovených tímto zákonem : Aby byla určitá činnost živností, je nutné kumulativni naplněni všech uvedených podmínek. Nelze přehlédnout, že uvedená definice se do značné miry překrývá s definici podnikáni dle § 2 odst. 1 obchodního zákoniku. S určitou mírou zjednodušení je tedy živností podnikání za podminek stanovených živnostenským zákonem. Dle přilohy č. 4, bodu 74 nařizení vlády č. 278/2008 Sb. je obsahem náplně živnosti volné ,Provozováni tělovýchovných zařizení a organizování sportovní činnosti ' mimo jiné též , [č]innost výkonných sportovcü, prípadně rozhodčich, provozovaná samostatně a za účelem dosažení zisku'. V§ 3 živnostenského zákona je uveden taxativní výčet činností, které nejsou živnostmi, přestože svým obsahem mohou naplňovat všechny znaky podnikání. Jedná se zejména o činnosti, jejichž výkon je regulován zvláštními právními předpisy. Činnost výkonných sportovcù v tomto výćtu zahrnuta není. [...] Nejvyšši správní soud je toho názoru, že pokud je s ohledem na neujasněnost právní úpravy v zásadě možné vykonávat samostatnou činnost profesionálního sportovce dle $\S 7$ zákona o danich z př́jmů bud'to jako živnostenské podnikání, nebo jako nezávislé povolání, nelze za daného právního stavu daňový subjekt nutit, aby zvolil ten zpưsob, kterýje vhodnějši z hlediska fiskálnich zájmů státu."20

Na tomto základě je tak dále petrifikována stávající praxe sportovců, kteří se živí podáváním sportovních výkonů ve prospěch klubů, přičemž je nově soudy napevno dáno i to, že v rámci kategorie OSVČ se připouští obě myslitelné varianty, tj. včetně daňově výhodnější varianty s živnostenským oprávněním.

Úpravě právního postavení hráčů byla $\mathrm{v}$ tomto příspěvku věnována výše rozsáhlá pozornost $\mathrm{z}$ toho důvodu, že praxe $\mathrm{v}$ př́ípadě trenérů je velmi podobná, avšak není $\mathrm{k}$ ní dostupná takto poměrně ucelená judikatura. Závěry soudů o principu smluvní volnosti ve vztahu k volbě druhu smluvního vztahu je nutné brát mutatis mutandis za obecně platné i pro výkon „trenérského řemesla“ v naší zemi. Jistě není důvod uvažovat, že trenérství je výrazně odlišné od principů fungování profesionálních sportovců, co se jejich vztahu s klubem týče.

20 Srov. odst. 28, 29, 35 citovaného rozsudku. 
Z hlediska smluvního lze tudíž v př́ípadě trenérů a jejich kontraktačních partnerů, tj. v našem uvažovaném prŕpadě nejčastěji klubů, v prŕípadě individuálních sportů ovšem i jednotlivců jakožto profesionálních sportovců v tenise, lyžování apod., hovořit o široké smluvní volnosti.

V profesionálním a poloprofesionálním sportu se budeme nejčastěji setkávat s trenérskou činností v režimu OSVČ, a to zpravidla se živnostenským oprávněním (volná živnost, srov. výše citaci z rozsudku Nejvyššího správního soudu spis. zn. 6 Afs 278/2016-54). Smluvním základem, jímž jsou tito trenéři vázáni ke klubům či individuálním sportovcům, bude nejčastěji inominátní smlouva podle $\S 1746$ odst. 2 OZ. ${ }^{21}$ Dalším smluvním typem, se kterým je možno se eventuálně též setkat a jenž připouští i judikatura, je smlouva příkazní (dříve též mandátní). ${ }^{22} \mathrm{Z}$ povahy věci nepůjde u trenérských př́kazních smluv vykonávat činnosti pro př́kazce jinak než osobně, snad s výjimkou toho, že může být dáno oprávnění trenéra některé činnosti delegovat např. na své asistenty.

Forma činnosti trenéra jako OSVČ však není pochopitelně jedinou, kterou můžeme v mnohoúrovňovém sportu v České republice najít. Nepochybně se lze setkat dokonce i s variantami, že v rámci jednoho a toho samého sportovního klubu působí někteří trenéři např. na základě inominátní smlouvy, zatímco jiní trenéři budou vykonávat své povinnosti třeba na základě dohody o provedení práce či dohody o pracovní činnosti. Dohody o pracích konaných mimo pracovní poměr jsou v praxi sportovních klubů relativně hojné na nižších úrovních soutěží, které z důvodů ekonomických i výkonnostních neumožňují či nevyžadují angažování trenéra v plném rozsahu. Klasický pracovní poměr se $\mathrm{v}$ př́padě trenérů $\mathrm{v}$ praxi nevyskytuje $\mathrm{s}$ ohledem na obdobné omezující skutečnosti, jež byly vypočteny výše ve vztahu k hráčským smlouvám.

Z hlediska smluvního zakotvení činnosti trenéra je vhodné dbát v praxi na to, aby byly dostatečně uspokojivě formulovány především podmínky skončení právního vztahu klubu a trenéra. V tuzemských poměrech vrcholných soutěží je spiše výjimkou, aby trenér na své pozici vydržel po celou dobu předvídanou ve smlouvě. Obvykle jsou trenéři tzv. odvoláni z důvodu neuspokojivých soutěžních výsledků mužstva, v některých případech ale může dojít i $\mathrm{k}$ předčasnému ukončení $\mathrm{z}$ důvodu angažování kouče na trenérskou lavici některého prestižnějšího klubu či reprezentačního výběru. Před orgány rozhodujícími spory ze smluv mezi trenéry a kluby ${ }^{23}$ je zpravidla jednou z hlavních sporných otázek otázka finančního plnění klubu vůči trenérovi k okamžiku ukončení smluvního vztahu. Lze proto doporučit, že obě strany by měly věnovat „výstupním klauzulím ze smlouvy“ zvýšenou pozornost už během předkontraktačního vyjednávání, aby tak minimalizovaly následné spory v okamžiku rozvazování smlouvy, kdy už vzájemné vztahy a možnosti racionální dohody nemusí být nejlepší. Již při uzavření smlouvy by mělo být co možná nejprecizněji ve smlouvě stanoveno, za jakých okolností

21 Tj. „Strany mohou uzavřit i takovou smlouvu, která není zvláště jako typ smlouvy upravena.“

22 Srov. nález Ústavního soudu ze dne 25. 10. 2006, spis. zn. II. US 686/05. Mandantem/př́kazcem je v takovém případě klub, pro nějž obstarává mandatár/prííkazník - trenér určité záležitosti spojené s př́ipravou sportovců.

23 V praxi jde o orgány jednotlivých sportovních svazů, popř. na mezinárodní úrovni o Mezinárodní rozhodčí soud pro sport se sídlem Lausanne (Court of Arbitration for Sport). 
může klub či trenér smlouvu vypovědět a jaké to bude mít následky. Lze zvážit vložení ustanovení o okamžitém ukončení právního vztahu, ukončení dohodou, ukončení s výpovědní dobou, práva a povinnosti stran při běhu výpovědní doby, vypověditelnost pouze k určitým termínům v roce, odstoupení atd. Zcela zásadní je v profesionálním prostředí stanovit, zda „propuštěný“ trenér bude mít nárok na vyplacení celé odměny garantované smlouvou až do jejího konce, či zda bude tato částka krácena, popř. trenérovi po předčasném skončení smluvního vztahu další plnění od klubu nepřipadne. Tím spíše je výše uvedené nutno brát v potaz vzhledem k tomu, že trenérské smlouvy v České republice nebývají pracovními smlouvami.

Znění smluv často nad tento rámec může naopak obsahovat i stanovení tzv. opčního práva klubu požadovat u trenéra přednostní prodloužení smlouvy ještě před jejím vypršením, pokud je klub s prací trenéra spokojen. V takovém př́padě je naopak vhodné již do původní smlouvy jasně specifikovat podmínky, za kterých může být opce uplatňována, zpravidla se vyžaduje, aby odměna trenérovi byla navýšena $\mathrm{v}$ řádu několika desítek procent. ${ }^{24}$

Nakonec by neměla být zapomenuta i v praxi amatérského sportu zcela zásadní rovina, kdy osoba pro klub či sportovce vykonává trenérskou činnost na ryze dobrovolné bázi a bez nároku na jakoukoliv odměnu. $V$ takovém případě neexistuje mezi subjekty ani uzavřená písemná smlouva, ledaže by např. trenér byl členem daného sportovního spolku, což lze považovat za specifický formální smluvní vztah. ${ }^{25} \mathrm{~V}$ př́ípadě zvláštních situací (např. odpovědnost za škodu, ukončení činnosti trenéra) by bylo nutno přihlédnout k obecnému soukromoprávnímu rámci pro jakékoliv jiné oblasti lidské činnosti či eventuálně $\mathrm{k}$ právům a povinnostem člena spolku daného př́slušnými stanovami sportovního klubu.

\section{INTERNÍ REGULACE ČINNOSTI TRENÉRŮ V RÁMCI SPORTOVNÍCH ASOCIACÍ}

Jak bylo základně vymezeno již v úvodní pasáži této stati, činnost sportovních trenérů bývá nezř́ídka nad rámec obecného právního řádu (resp. přesněji řečeno v limitech jeho dispozitivnosti) dále regulována uvnitř sportovních asociací. Trenérská činnost $v$ jejich sféře vlivu, tj. v příslušném sportovním odvětví, které daná asociace spravuje, je dále usměrňována jak interními normativními předpisy, tak také např. nezávaznými metodickými pokyny. Pokud projdeme strukturu orgánů a odborných komisí sportovních svazů některých nejpopulárnějších sportů v České republice, nalezneme u řady z nich tzv. trenérské komise. ${ }^{26}$ Jejich oprávnění navazují obvykle na stanovy či na jejich základě přijímané interní předpisy svazů.

24 Srov. Rozhodnutí CAS 2014/A/3852 Ascoli Calcio 1898 S.p.A v. Papa Waigo N'diaye \& Al Wahda Sports and Cultural Club ze dne 11. 1. 2016. Dostupné online na: <http://jurisprudence.tas-cas.org/Shared\%20 Documents/3852.pdf> [cit. 31. 10. 2018].

25 Založeného na přihlášce za člena spolku a následném rozhodnutí orgánu spolku o přijetí za člena spolku.

26 Např. Trenérská komise Českého svazu ledního hokeje; v rámci FAČR je možno nalézt tzv. Úsek trenérsko-metodický jako součást Sportovně-technického oddělení; v rámci UEFA má danou oblast na starosti 
Tyto interní předpisy a z nich plynoucí požadavky na výkon činnosti trenéra jsou závazné pro kouče $\mathrm{v}$ tom rozsahu, $\mathrm{v}$ jakém neodporují obecně platným právním pravidlům. Jelikož trenérské smlouvy mnohdy obsahují přímý odkaz na závaznost pravidel př́slušné sportovní asociace pro daný právní vztah mezi trenérem a klubem, lze uvažovat v tomto smyslu o jakési ,inkorporační klauzuli“, která interní normativní rámec sportovní asociace vtahuje do obsahu vzájemných práv a povinností mezi stranami takovéto smlouvy. Obecně to platí více pro prípady smluvních vztahů hráčů a klubů, které přeci jen bývají sportovními asociacemi více regulovány ${ }^{27}$, ale též pro trenérské smlouvy mohou být některé asociační regule podstatné.

Výše uvedené je relevantní nejen pro utvrzení vzájemných práv a povinností mezi kluby a trenéry, ale v jistém směru i pro vztah trenéra vůči sportovní asociaci. Dalším podstatným prvkem činnosti trenéra $\mathrm{v}$ odvětvích regulovaných do větší či menší míry zastřešujícími sportovními asociacemi je totiž i mandatorní členství trenéra $\mathrm{v}$ této asociaci - spolku. Vázanost člena spolku vnitřními pravidly této právnické osoby v nejširším slova smyslu plyne již z § 233 odst. $2 \mathrm{OZ}$, povinnost člena podřídit se interním spolkovým pravidlům a rozhodnutím spolkových orgánů však bývá standardně zakotvena též ve stanovách těchto právnických osob.

Jako př́klad je možno vzít interní rámec fungování FAČR, která ve svých stanovách $^{28}$ určuje, že trenéři jsou tzv. členy se zvláštními členskými právy a povinnostmi (čl. 9 odst. 4 písm. b) stanov). Členem FAČR se s těmito zvláštními právy a povinnostmi stává fyzická osoba mající již členství ve FAČR ,na základě ziskání trenérské licence v souladu s Řádem trenérư s tím, že tento její zvláštni status vzniká okamžikem, kdy je získání trenérské licence vloženo do centrální evidence členství."29

Výkon funkce trenéra především na nejvyšších úrovních př́islušných sportů (tj. na úrovni výkonnostního či profesionálního sportu) je obvykle vázáno na získání určité formální licence udělované sportovním svazem na základě jeho standardů či standardů daných nadřazenou mezinárodní asociací př́slušného sportu.

V př́ípadě největšího českého sportovního svazu, co se členské základny týče, FAČR, je hlavním interním předpisem pro činnost trenérů aktuálně platný Řád trenérů Fotbalo-

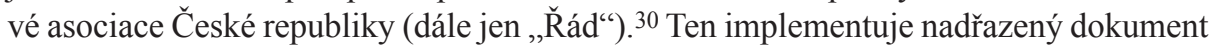
UEFA, kterým je Konvence o vzdělávání evropských trenérů UEFA (dále jen „Konvence“), k níž se FAČR přihlásila. ${ }^{31}$ Rád FAČR na tuto Konvenci totiž výslovně odkazuje

Development and Technical Assistance Committee; mezinárodní hokejová federace IIHF zase zř́dila Coaching Committee.

27 Viz poznámka pod čarou č. 41.

28 Stanovy FAČR účinné ke dni 1. 8. 2018. Dostupné online na: <https://facr.fotbal.cz/uredni-deska-predpisy /206? category $=1>$ [cit. 31. 10. 2018].

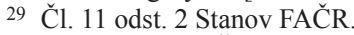

30 Aktuální znění Řádu trenérů je účinné od 1. července 2017. Dostupné online na: <https://facr.fotbal.cz /uredni-deska-predpisy/179? category=1> [cit. 31. 10. 2018].

31 UEFA Coaching Convention ze dne 4. prosince 2014. Tuto „konvenci“ přijal Výkonný výbor UEFA (Executive Committee) a jde o specifický vnitrospolkový nástroj UEFA: není pro členy UEFA bezprostředně závazný, pokud se sami nerozhodnou $\mathrm{k}$ němu přistoupit, jedná se tedy o určitou paralelu $\mathrm{k}$ instrumentům smluvního práva v klasickém mezinárodním právu veřejném $\mathrm{s}$ tím rozdílem, že $\mathrm{v}$ tomto př́ípadě se universum subjektů, kterých se může takováto „konvence“ týkat, vyčerpává s počtem členských národních fotbalových asociací UEFA (v současnosti UEFA sdružuje 55 těchto asociací). UEFA Coaching Conven- 
ve svém čl. 1 odst. 3 , lze tak dovozovat, že i s ohledem na obecné principy sportovního/ spolkového práva a tzv. pyramidální strukturu sportovních odvětví bude Konvence sloužit jako rozšiřující výkladový a aplikační rámec Řádu. V př́ípadě, že by ustanovení Rádu nebyla v souladu s ustanoveními této Konvence, podobně jako v př́ípadech jiných spolkových pravidel FAČR by bylo možné domáhat se přímé aplikace nadřazeného předpisu UEFA.

Toto obecné pravidlo fungování národních sportovních spolků ve vztahu k regulativní pravomoci nadřazených mezinárodních sportovních asociací lze v případě FAČR dovozovat mimo jiné i z prŕmého závazku v čl. 4 odst. 1 jejích Stanov, v němž se uvádí, že FAČR ,je členem FIFA a UEFA. Na tomto základě plně respektuje jejich predpisy, které jsou pro ni závazné, a zajištuje respektováni těchto predpisů svými členy cestou vydávání svých vnitřnich predpisü." 32

$\mathrm{S}$ ohledem na omezený rozsah tohoto článku i skutečnost, že v jiných sportech se může dílčím způsobem úprava výkonu trenérské funkce lišit, bude na tomto místě dále poukázáno pouze v krátkosti na hlavní principy regulace vtělené do Řádu FAČR.

Cílem tohoto vnitrospolkového předpisu je v nejširším slova smyslu „vzdělávání trenérů tak, aby bylo možno ziskat, zachovat a zvyšovat odbornou způsobilost trenérů $k$ dosažení co možná nejkvalitnějšího tréninkového procesu a pozitivního vývoje ve výkonnosti hráču. “"33 Za tímto účelem Rád nastavuje systém trenérských licencí jako podmínku výkonu trenérské činnosti v soutěžích organizovaných pod FAČR. ${ }^{34}$ Licence je oprávněna udělovat FAČR bud' samostatně (v př́ípadě nejvyšších typů licencí), popř. tuto agendu částečně delegovala na tzv. okresní a krajské fotbalové svazy, které v českém fotbalovém prostředí působí ve formě pobočných spolků FAČR ve smyslu $§ 228$ a násl. OZ.

Licence se člení na ty, které vycházejí př́mo z Konvence, a ty, které zavádí sama FAČR. Pro jednotlivé úrovně soutěží je předepisován požadavek na konkrétní druh trenérské licence opravňující osobu funkci trenéra na takové úrovni zastávat, přičemž pro nejvyšši soutěž v kategorii mužů je striktně trváno na licenci typu UEFA PRO, jež vychází z Konvence (pro trenéry brankářů je však pro tuto soutěž předepisována licence „Trenér brankářů A“ založená na licencích FAČR). Pro každý typ licence je stanovován jiný rozsah vzdělávacích kurzů, v př́ípadě uchazečů, kteří splňují kritéria určitého počtu odehraných zápasů za národní reprezentační tým a/nebo v nejvyšších soutěžích jednotlivých členských asociací FIFA je možno získat některé typy licencí i ve zrychleném režimu tzv. „fast track“.35

tion dostupná online na: $<$ https://www.uefa.com/MultimediaFiles/Download/uefaorg/CoachingCoachedu /02/29/42/76/2294276_DOWNLOAD.pdf> [cit. 31. 10. 2018].

32 Z druhé strany i UEFA zavazuje své členské národní asociace respektovat její předpisy - srov. čl. 7 Stanov UEFA. Dostupné online na: <https://www.uefa.com/MultimediaFiles/Download/uefaorg/General /02/54/12/62/2541262_DOWNLOAD.pdf>_[cit. 31. 10. 2018].

33 Čl. 1 odst. 2 Řádu.

34 Eventuálně dle čl. 4 odst. 5 Stanov FAČR také soutěžích organizovaných na základě smlouvy s FAČR prostřednictvím Ligové fotbalové asociace, z. s.

35 Srov. např. pro licenci UEFA PRO předpokládaný rozsah 543 hodin strukturovaný do mnoha tematických bloků obsahujících teorii, praxi i stáže. Osvojení si znalostí a dovedností je předmětem zkoušek. Viz Př́íloha č. 5 Řádu. 
Systém licencí je navzájem podmíněn tak, že pro absolvování kurzu licence určitého stupně se zpravidla předepisuje, že uchazeč musí být držitelem licence bezprostředně předcházející nižší úrovně. Licence založené na Konvenci jsou považovány za navzájem uznatelné, at' je vydala jakákoliv z členských asociací UEFA, takže na tomto základě může v české nejvyšší fotbalové soutěži působit např. italský fotbalový trenér, aniž by musel licenci získat v České republice. Licence vyšších úrovní jsou ve své platnosti zpravidla časově omezeny, ̌̌ád proto nastavuje pravidla tzv. doškolování trenérů, jež musí každý držitel takto omezené licence absolvovat, aby si svou licenci udržel. Trenérské kurzy jsou ze strany FAČR akreditovány u Ministerstva školství a jejich absolvent při splnění předepsaných povinností obdrží od FAČR jednak „diplom“ a jednak trenérský průkaz a pro nejvyšší soutěže i visací kartu, kterou se může v rámci soutěžních utkání prokazovat.

V celkovém kontextu spolkové regulace (demonstrované na př́íkladu FAČR) je možno tedy uzavřít, že pro výkon trenérství v rámci regulovaných sportovních/soutěžních odvětví je rámec právního vztahu trenéra ke sportovnímu klubu, popř. k zastř̌šující sportovní asociaci značně rozšířen právě o tyto spolkové povinnosti. Nejen pro trenéry tak platí, že nestačí, aby uzavřeli svou soukromoprávní smlouvu s klubem jakožto druhou smluvní stranou, nýbrž musí plnit i povinnosti ukládané sportovní asociací. $\mathrm{V}$ prrípadě, že by trenér např. nedisponoval pro určitou kategorii soutěží př́slušnou licencí či nebyl přes výslovný požadavek sportovní asociace jejím registrovaným členem, jeho smlouva by de facto ve vztahu ke sportovnímu prostředí byla neúčinná. Ačkoliv by tak mohl vzniknout na první pohled platný soukromoprávní závazek mezi klubem a „trenérem“, takováto fyzická osoba by nemohla vystupovat na oficiálních pozicích při žádném oficiálním utkání hraném podle soutěžních pravidel dané asociace. Pokud by byla tato pravidla porušena, mohl by naopak být trenér ${ }^{36} \mathrm{a} /$ nebo klub ze strany ř́dící sportovní asociace sankcionován na základě disciplinárního či obdobného řádu. ${ }^{37}$ Dalším možným důsledkem vnitrospolkové neúčinnosti takové smlouvy by mohlo za některých okolností být i to, že by plnění z ní nebylo možno vynucovat $\mathrm{v}$ rámci interních kvazi-arbitrážních orgánů, které jinak za účelem zachování smluvní stability v rámci sportovních vztahů sportovní asociace obvykle zřizují. ${ }^{38}$

Jinou otázkou, $\mathrm{v}$ právní teorii i praxi zatím neřešenou, je $\mathrm{v}$ takovém případě vynutitelnost plnění z takové smlouvy před obecnými soudy. ${ }^{39} \mathrm{Tj}$. zda by se soudy striktně držely ustanovení smlouvy, která by nebyla v rozporu s obecně platným právním řádem, či zda by šly nad tento rámec a byly ochotny přihlédnout i k jejímu širšímu kontextu, kterým je celá regulace výkonu trenérské činnosti v předpisech sportovních asociací. Domnívám se, že s ohledem na posouzení institutů a principů namítaných př́ípadně v tomto hypotetickém právním sporu jednou ze stran, by se soud musel (i pokud by daná

36 Za předpokladu, že by byl členem sportovní asociace.

37 Srov. např. § 50 Disciplinárního řádu FAČR. Dostupné online na: $<$ https://facr.fotbal.cz/uredni-deska-predpisy/221?category $=1>$ [cit. 31. 10. 2018].

38 Srov. poznámka pod čarou č. 23.

$39 \mathrm{Tj}$. např. byla-li by uzavřena takováto trenérská smlouva podle $\S 1746$ odst. $2 \mathrm{OZ}$, avšak nebyly by splněny podmínky pro její „účinnost ve sportovním prostředí", např. pokud by se trenér nemohl aktivně zapojovat do soutěží organizovaných sportovní asociací. Sportovní klub by na základě této skutečnosti hypoteticky přstal trenérovi vyplácet smluvně sjednané odměny. 
smlouva neobsahovala př́mý „,inkorporační“ odkaz na spolková pravidla) tímto širším rámcem meritorně zabývat, a to např. s ohledem na otázky uzavření smlouvy v dobré viře a zákazu prospěchu z vlastní nepoctivosti (§ $6 \mathrm{OZ}$ ), či nemožnosti splnění smlouvy od jejího počátku jakožto důvodu neplatnosti smlouvy ( $\$ 579$ a $580 \mathrm{OZ}$ ).

Při uzavírání trenérských smluv je proto praktické, aby smluvní strany do smlouvy zahrnuly výslovné ustanovení, že trenér je povinen disponovat (nejpozději k určitému datu) trenérskou licencí př́slušné kategorie. $V$ príípadě nesplnění tohoto závazku si může klub ve smlouvě utvrdit, že se z jeho pohledu jedná o takový nedostatek, který jej opravňuje od smlouvy odstoupit podle § 2001 a násl. OZ. To je myslitelné za předpokladu, že většina trenérských smluv je v České republice uzavírána v podobě inominátních smluv podle $\mathrm{OZ}$ a nikoliv jako smlouvy pracovní. ${ }^{40}$

Na rozdíl od profesionálních hrášských smluv nemá FAČR nikde daný povinný obsah smlouvy pro trenéry. ${ }^{41} \mathrm{Z}$ hlediska smluvních vztahů mezi klubem a trenérem tak neexistuje jednotné vodítko toho, jaká ustanovení by měla smlouva obsahovat a na smluvní strany jsou proto kladeny vyšší nároky při sjednávání smlouvy, za jejíž obsah nepřebírá $\mathrm{v}$ tomto př́padě FAČR žádnou odpovědnost. Na rozdíl od profesionálních hráčských smluv nejsou trenérské smlouvy u FAČR ani předmětem registrace, registrují se v evidenci členů FAČR pouze trenérské licence spolu se základními údaji o jejich držitelích. ${ }^{42}$

\section{SHRNUTÍ}

Jak již bylo znát z exkurzu do úpravy trenérské profese na Slovensku, nelze popis české situace předložený $\mathrm{v}$ tomto textu zevšeobecňovat i pro situaci v zahraničí. V prŕípadě angažování trenérů s mezinárodní prestiží se může stát, že „slabší smluvní stranou" nebude v takovém př́ípadě trenér, nýbrž fakticky klub. Traduje se, že když byl do české nejvyšší fotbalové ligy dojednáván př́íchod zahraničního trenéra ze západní Evropy, nebyl to klub, kdo předložil návrh smlouvy, ale právě trenér sám, který

$40 \mathrm{~V}$ př́ípadě výkonu trenérské činnosti v režimu pracovněprávních vztahů by nešlo v takovémto případě ukončit pracovní poměr s okamžitým účinkem, a to proto, že absence příslušné licence není v př́ipadě trenéra porušením právních předpisů nýbrž „pouze“ interních norem spolku (srov. § 55 odst. 1 písm. b) $\mathrm{ZP)}$. Z hlediska výpovědi zaměstnanému trenérovi by pak přicházela v úvahu pouze aplikace $\S 52$ písm. f) $\mathrm{ZP}$, „nesplňuje-li [trenér] bez zaviněni zamèstnavatele požadavky pro rádný výkon této práce.“ $\mathrm{V}$ př́padě dohod o pracích konaných mimo pracovní poměr by pak přicházelo $\mathrm{v}$ úvahu zrušení cestou výpovědi ze strany klubu podle $§ 77$ odst. 4 písm. b) ZP.

41 K povinným náležitostem hráčské profesionální smlouvy FAČR srov. čl. 18-22 Přestupního řádu FAČR; dostupné online na https://facr.fotbal.cz/uredni-deska-predpisy/216?category=1 [cit. 31. 10. 2018]. I tato úprava čerpá z evropského fotbalového prostředí, když implementuje požadavky plynoucí z Autonomní dohody o minimálních požadavcích na standardní hráčské smlouvy (Autonomous Agreement on Minimum Requirements for Stadard Player Contracts) ze dne 19. 4. 2012. Dostupné online na: $<$ https://fifpro.org/attachments/article/5292/Autonomous\%20Agreement\%20on\%20Minimum\%20 Requirements\%20for\%20Standard\%20Player\%20Contracts.pdf> [cit. 31. 10. 2018]. Ta vznikla na základě evropského sociálního dialogu ve smyslu čl. 155 SFEU, během nějž se na pravidlech vtělených do této dohody společně usnesly zástupci UEFA, EPFL (European Professional Football Leagues), FIFPro Division Europe (evropská pobočka organizace zaštit'ující fotbalové hráče - Fédération Internationale des Associations de Footballeurs Professionnels) a ECA (European Club Association).

42 Srov. $§ 6$ a $§ 29-31$ Evidenčního a registračního řádu FAČR. 
základní pracovní verzi smlouvy přichystal a předložil ji k dalšímu jednání. V takových př́padech může být i zcela vyloučena aplikace právního řádu České republiky, jelikož se (nikoliv pracovněprávní) smlouva rrídí právem jiného státu. Na druhou stranu při působení v soutěži organizované pod hlavičkou FAČR (či Ligové fotbalové asociace) ani toto nebude na překážku plné aplikovatelnosti českých spolkových předpisů na pozici trenéra. Trenér tak musí být napřs. pro nejvyšší fotbalovou ligu v držení předepisované licence UEFA PRO, jíž mohl ale získat u jiné členské asociace UEFA, a plnit $\mathrm{k}$ tomu další povinnosti plynoucí z regulí FAČR, UEFA či FIFA. Spolková regulace je tudíž pro sportovní trenéry mnohdy zcela klíčovou otázkou, at’ již je jejich právní vztah s klubem založen na jakémkoliv smluvním typu.

Do budoucna lze i v České republice očekávat posun k širší regulaci sportu tak, jak se tomu děje v řadě okolních evropských států. Lze se proto domnívat, že legislativní pozornosti nakonec neunikne ani otázka právní úpravy smluv sportovců a dalších osob na sportu se podílejících, tedy i trenérů. Pravděpodobně tak dřive či později u nás projde proměnou i současný systém výkonu trenérské činnosti z pohledu práva.

JUDr. David Kohout, Ph.D.

Právnická fakulta Univerzity Karlovy

kohout@prf.cuni.cz 